\title{
Laryngopharyngeal Reflux Disease: Diagnosis and Treatment in 2021
}

\author{
Jeong Wook Kang (1) and Young-Gyu Eun (1) \\ Department of Otolaryngology-Head and Neck Surgery, Kyung Hee University School of Medicine, Seoul, Korea
}

인후두 역류 질환: 진단 및 치료

강정욱, 은영규

경희대학교 의과대학 이비인후과학교실

\begin{abstract}
Laryngopharyngeal reflux disease (LPRD) is an inflammatory condition of the upper aerodigestive tract mucosa induced by reflux content from stomach. Some of vocal cord diseases are associated with laryngopharyngeal reflux. Because of the pathophysiological features, proton pump inhibitor shows therapeutic effect on some vocal cord diseases. As like that, the gastric reflux contents can make macroscopic or microscopic morphological changes in the upper aerodigestive tract mucosa. Although the pathophysiology of LPRD is relatively clear, clinical diagnosis is still difficult. The diagnosis of LPRD includes objective tests such as 24-hours multichannel intraluminal impedance-pH metry and subjective tests such as questionnaire method. However, the objective verification of reflux is difficult due to invasiveness of the method, and the questionnaire methods have limitations because many symptoms are not specific for LPRD. Moreover, most methods are not fully standardized until now. Despite these limitations, many researchers are struggling to standardize diagnosis and treatment of LPRD, and there are several new achievements recently. Therefore, the purpose of this article is to review the recent literature on the clinical presentation, diagnosis, and treatment of LPRD, and to systematize our knowledge.
\end{abstract}

Keywords Laryngopharyngeal reflux; Diagnosis; Treatment.

\section{서 론}

인후두 역류질환(laryngopharyngeal reflux disease)은 위 십이지장 내용물 역류의 직간접적 영향에 의한 상부 소화호흡기관(upper aerodigestive tract)의 염증 상태로, 상 부 소화호흡기 조직의 형태학적 변화를 유도한다[1]. 이 정의는 인후두뿐만 아니라 모든 상부 소화호흡기관 점막을 자극하는 일부 십이지장 분자의 자극을 고려하지 않았던 미 국이비인후과학회-두경부외과(American Academy of Otolaryngology-Head and Neck Surgery, AAO-HNS)의 과거 2002년 권고안의 정의와 다르다[2-4]. 이 정의는 일부 증 상은 신경 반사 및 미주신경의 보상작용에 의해 야기될 수 있다는 다인적 요인의 가능

\author{
Received March 24, 2021 \\ Revised May 8, 2021 \\ Accepted June 15, 2021
}

\section{Corresponding Author}

Young-Gyu Eun, MD, PhD

Department of Otolaryngology-

Head and Neck Surgery,

Kyung Hee University School of Medicine,

23 Kyungheedae-ro, Dongdaemun-gu,

Seoul 02447, Korea

Tel +82-2-958-8474

Fax+82-2-958-8470

E-mail ygeun@khu.ac.kr

\section{ORCID iDs}

Jeong Wook Kang (D)

https://orcid.org/0000-0002-0305-1255

Young-Gyu Eun (1)

https://orcid.org/0000-0003-4081-5207

This is an Open Access article distributed under the terms of the Creative Commons Attribution Non-Commercial License (https://creativecommons.org/ licenses/by-nc/4.0) which permits unrestricted non-commercial use, distribution, and reproduction in any medium, provided the original work is properly cited. 
성을 내포한다[5]. 지난 30년 동안 인후두 역류질환에 대한 간행물 수가 점진적으로 증가하고 관심도 높아졌지만 임상적 접근, 진단 및 치료를 다룰 때 여전히 많은 논란이 있다[6]. 이 종설은 인후두 역류질환의 임상 발표, 진단 및 치료에 대한 최근 문헌을 검토해보고 현시점의 인후두 역류질환에 대한 우리의 지식이 어디까지 왔는지 돌아보고자 하였다.

\section{본 론}

\section{역 학}

인후두 역류질환을 상부 소화호흡기관에서 가장 빈번하게 발생하는 만성 염증 상태 중 하나로 보는 견해가 있지만 명확 한 진단기준의 부재로 인해 정확한 발생률과 유병률은 아직 까지 확정하기 어렵다. 이비인후과 외래 환자의 $10 \%$ 에서 인후 두 역류질환이 발생한다고 추정한 Koufman[7]의 초기 연구 이후 소수의 역학 연구만이 발표되었다. 중국과 그리스에서 인후두 역류질환 유병률은 각각 5\%와 $18.8 \%$ 로 추정되었으나, 이러한 평가는 진단을 내리기에는 불충분한 환자가 작성한 설문지를 기반으로 추정한 것이라는 한계가 있다[8,9]. 음성 센터에서 시행한 또 다른 연구에서는 인후두 역류질환 유병 률에 대한 평가가 5개월 동안 수행되었고, $\mathrm{pH}$ 모니터링을 통 해 환자의 69\%가 인후두 역류질환 증상을 보였고 전체 환자 의 $50 \%$ 에서 $\mathrm{pH}$ 모니터링 양성 결과를 얻었다고 보고했다 [10]. 이 초기 보고서 이후 객관적인 검사를 통해 음성 센터에 서 인후두 역류질환의 발생률 또는 유병률을 평가한 연구는 찾아보기 어려웠다.

\section{임상 증상과 징후}

인후부 이물감, 헛기침, 쉰 목소리, 과도한 인후 점액 및 후 비루는 인후두 역류질환 환자의 최소 $75 \%$ 에서 발견되는 가 장 흔한 증상이다[11-13]. 지금까지 이 주제에 대해 수행된 가 장 대규모 연구인 progression of gastroesophageal reflux disease (ProGERD) 연구의 초기 분석에 따르면, 인후두 증 상은 일반적으로 위식도 역류질환(gastroesophageal reflux disease) 환자의 32.8\%와 관련이 있었다[14]. Dore 등[15]이 수 행한 다른 연구에서는 위식도 역류질환 환자에서 가장 빈번 한 이비인후과 증상으로 인후부 이물감(39\%), 트림(26\%), 기 침(24\%) 및 쉰 목소리(23\%)를 확인하였다. 속쓰림과 같은 고 전적인 위식도 역류질환 증상은 일반적으로 위식도 역류질 환에 비해 인후두 역류질환에서 덜 빈번하였다[16]. 그러나 최 근의 발견은 흥부작열감(heartburn), 역류(regurgitation), 흥 골하 통증(retrosternal pain), 연하곤란(dysphagia) 같은 위 식도 역류질환의 고전적 증상이 인후두 역류질환에서도 예측
했던 것보다 더 자주 동반된다는 것이다[16-19]. 최근의 발견 에 따르면, 후교련부 비대(posterior commisure hypertrophy), 후두 내 점액 증가 및 후두 홍반이 가장 흔한 인후두 역류의 내시경 징후였다[11-13]. Chen 등[20]이 수행한 91명의 건강 한 개인을 대상으로 한 코호트 연구에서도 후두 홍반, 후교련 부 비대 및 미만성 후두 부종이 가장 일반적인 인후두 역류 징후였다. 최근 연구에서는 이러한 증상과 징후의 유병률이 성별과 연령에 따라 크게 다를 수 있다고 주장한다[21-23]. 특 히 노인 환자가 잘 인지하지 못하는 위식도 역류질환 증상의 경우는 더 그러할 수 있다. 또한 일부 인후두 역류질환의 증상 과 징후는 건강한 개인에게서 발견되는 경향이 있다. 헛기침 및 과도한 인후 점액은 건강한 개인에게서도 발견되는 인후 두 역류질환의 일반적인 증상과 징후였다[20]. Hicks 등[24]도 유사한 결과를 보고하였는데 건강한 사람들의 $86 \%$ 가 인후 두 역류 징후를 가지고 있다고 보고했으며 후교련부 비대 같 은 징후는 유병률이 $70 \%$ 에 이른다고 했다. 다만 연구자들이 평가 결과의 신뢰성에 큰 영향을 미치는 개인의 임상 상태를 알고 있는 건강한 사람들의 징후를 평가했기 때문에 이러한 결과는 신중하게 해석할 필요성이 있다[25,26].

병 인

인후두 역류질환는 상부 소화호흡기관 점막의 거시적 혹 은 미시적 변성에 의해 발생한다고 알려져 있다[27-29]. 펩신 (pepsin)이 점액의 분비와 중탄산염의 분비를 감소시키기 때 문에 점막 자극은 염증 반응을 일으키고 점도가 높은 점액의 과분비로 이어질 수 있다[3,28,30]. 점도가 높은 점액의 축적 은 후비루 느낌, 인후두 이물감 및 헛기침과 같은 증상을 유 발하여 결과적으로 인후두 불편감을 증가시킨다[31]. 점액 과 다 분비 및 관련 증상은 위의 역류 물질이 식도 원위부 점막 의 화학 수용체를 자극함으로써 발생할 수 있다[5,32]. 동시에 상부 소화호흡기관의 점막 염증은 연하 곤란, 인후두 이물감, 인후통 및 연하통 같은 증상을 유발할 수 있다. 쉰 목소리의 발달을 설명하는 병태 생리학적 기전은 더 복잡하며, 최근의 병태 생리학적 모델에 따르면 성대 점막의 조직학적 변화와 성대 주름의 생체역학적 변화가 실질적인 음성의 악화로 이어 질 수 있다[11,28,33,34].

최근 역류성 인후두염 증상을 가진 환자들과 정상인의 24 시간 다채널 내강 임피던스-산도 측정 검사(24-hour multichannel intraluminal impedance-pH monitoring)를 비교한 국내 연구에서 역류성 인후두염으로 진단된 환자군에서 하 인두 부위의 임피던스가 정상인에 비해 높게 유지되는 것으로 보고하였다[35]. 흥미로운 점은 역류성 인후두염 증상이 있는 환자에게서는 24시간 다채널 내강 임피던스-산도 측정 검사 
상 역류가 확인되지 않더라도 정상군에 비해 하인두 부위의 임피던스는 증가되어 있었다는 점이다. 해당 연구에서는 인 두 내강의 임피던스 증가 원인은 인두 내강이 좁아진 효과라 고 추측했다. 이 연구의 결과는 역류 이외의 인두의 내경을 좁아지게 만드는 다른 요인이 있을 가능성을 시사해준다. 이 에 대한 추가적인 연구가 필요할 것이다.

\section{진 단}

인후두 역류질환의 임상 진단 과정은 고전적 이비인후과 증 상과 함께 상세한 병력 청취를 하는 것으로부터 시작된다. 일 부에서는 안지오텐신 전환 효소(angiotensin onverting enzyme inhibitor)와 같은 약제에 의해 인후두 역류질환 유사 증상을 보이는 경우가 있으므로 복용 중인 약제를 포함한 상 세한 병력 청취가 필요하다. 다양한 환자 작성 설문지는 환 자 병력 문서화의 유용한 도구가 될 수 있다. 또한 설문지법은 시간 경과에 따른 증상의 변화와 치료 효과를 기록하고 평가 하는 데 도움이 된다.

\section{역류 증상 지수}

역류 증상 지수(reflux symptom index, RSI)는 Belafsky 등[36]에 의해 개발되었고 유효성이 검증되었으며 현재까지 도 널리 사용되는 환자 설문지법이다. 역류 증상 지수는 각 각 0-5점의 9개의 질문으로 구성되어 최소 0 점에서 최대 45 점의 점수로 환자의 증상을 평가한다. 점수가 높을수록 역류 증상이 크다는 것을 의미한다. 역류 증상 지수 검증 연구에 서 13점 미만이 정상인 것으로 발표되었으나 임상적으로는 10 까지를 정상으로 간주하기도 한다.

\section{인후두 역류질환에 대한 삶의 질 지수}

인후두 역류질환에 대한 삶의 질 지수는 Carrau 등[37]에 의해 개발되고 검증되었다. 산 역류의 전반적인 영향에 대한 평가 영역을 포함하여 5 개 영역으로 나뉜 43개의 질문으로 구 성되어 있다. 점수는 최저 9점에서 최고 256점까지로 평가되 며 점수가 높을수록 인후두 역류가 삶의 질에 미치는 영향이 크다는 것을 나타낸다.

\section{역류 증상 점수}

위식도 역류질환이나 인후두 역류질환 및 일부 호흡기 질 환 환자 간 증상의 유사성에 주목한 국제이비인후과연맹의 젊은 이비인후과 연구자들(Young Otolaryngologists of International Federation of Oto-rhino-laryngological Societies, YO-IFOS)은 인후두 역류질환, 위식도 역류질환, 폐 관련 질환의 증상을 평가하는 새로운 임상도구를 개발하
였다[38]. 그것은 역류 증상 점수(reflux symptom score, $\mathrm{RSS}$ 로 현재 각국의 언어로 번역되어 검증 중에 있다[39]. 역 류 증상 점수 설문지는 이비인후과 영역 9 개, 소화기 영역 9 개, 호흡기 영역 4개 증상에 대한 문항으로 이루어져 있다. 각 증상의 빈도와 중증도는 5점 척도로 평가되며 빈도와 관련된 점수는 각 항목별로 명확하게 정의되어 있다. 각 증상의 빈도 에 중증도를 곱하여 0 에서 25점까지의 점수가 나오면 이를 합 산하여 총점을 구한다. 삶의 질(quality of life)에 대한 각 증 상의 영향도 0 에서 5 점으로 평가하여 따로 합산한다. 역류 증 상 점수가 13점보다 크면(RSS>13) 인후두 역류질환 관련 증 상을 암시는 것으로 간주될 수 있다.

\section{4시간 다채널 내강 임피던스-산도 측정 검사}

24시간 다채널 내강 임피던스-산도 측정 검사는 현재까지 역류성 인후두염을 진단하는 데 가장 신뢰할 만한 검사법이 다. 비산성(nonacid) 역류의 중요성을 고려할 때 고전적인 $\mathrm{pH}$ 단독 측정 검사 대신 24시간 다채널 내강 임피던스-산도 측정 검사를 시행하는 것이 더 정확한 진단을 기대할 수 있 다[4,40,41]. 24시간 다채널 내강 임피던스-산도 측정 검사는 위산 역류뿐 아니라 일반적인 역류를 감지할 수 있으며, 약산 이나 알칼리 역류도 감지할 수 있다[41]. 검사결과에서 보고 되는 대부분의 측정치들은 인후두 역류질환 환자의 주관적 인 증상이나 삶의 질을 직접적으로 반영하지는 못한다[42]. 그러나 24시간 다채널 내강 임피던스-산도 측정 검사는 수많 은 인후두 역류질환의 진단 기준과 탐침(probe)의 위치에 관 계되어 있으며, 이것은 다양한 환자의 프로파일 선택에 기여 하고 있다[43]. 일반적으로 근위부 탐침은 상부 식도 괄약근 아래 $1 \mathrm{~cm}$ 또는 1-3 cm 위에 배치되고, 원위부 센서는 하부 식 도 괄약에서 $5 \mathrm{~cm}$ 위에 배치된다. 검사 기간 동안 근위부 탐침 의 움직임이 점막을 자극하여 이차적으로 역류와 유사한 증 상을 촉진할 수 있기 때문에 탐침을 식도 내에 위치해야 하는 지 하인두에 위치시켜야 하는지에 대한 논란이 있다[44]. 진 단 기준과 관련하여 최근 데이터에 따르면 인후두 역류질환 증상이 있는 환자에서 근위부 탐침에서 하나 이상의 역류 에 피소드가 있으면 비정상으로 보고 있으나 현재까지 국제적인 합의가 이루어진 단계는 아니다[43]. 진단 기준의 설정에는 다 수의 정상인에게 침습적인 24시간 다채널 내강 임피던스-산 도 측정 검사를 수행해야 하는 문제점이 있어 정상 값의 범위 를 명확히 할 수 없었기 때문에 현재까지도 표준화에 어려움 이 있다. 검사와 관련된 주요 문제점은 탐침 위치의 이상으로 인한 위양성이 $7 \%-17 \%$ 에 이르는 점과 24시간 검사 기간 동안 의 역류 에피소드의 부족으로 인한 위음성 가능성이 있다는 점이다[45-47]. 위음성 문제는 검사 시간을 48시간으로 늘림 
으로써 완화할 수도 있다. 이와 관련해 최근 연구에서 24시간 검사 대신 48시간으로 검사 시간을 늘린 환자에서 역류 에피 소드와 증상 간의 더 나은 상관 관계 분석을 보고한 바 있다 [48]. 해당 연구해서 실제로 48시간 검사가 24시간 검사에 비 해 횔씬 더 많은 역류 에피소드를 포착할 수 있었다[48].

\section{경험적 치료 시험}

많은 국가에서 24시간 다채널 내강 임피던스-산도 측정 검 사의 비용과 단점 때문에 경험적 치료 시험만 사용하여 인후 두 역류질환 진단을 내리는 이비인후과 의사의 수가 증가하고 있다[49,50]. 광범위하게 사용되고 있음에도 불구하고 경험적 치료 시험은 위식도 역류질환의 진단에는 유용할 수 있으나 인후두 역류질환에서는 유용성이 떨어진다고 알려져 있다. 기 존 증거는 양성자 펌프 억제제(proton pump inhibitor, PPI)에 대한 환자의 주관적 반응이 식도경 검사 및 24시간 다채널 내 강 임피던스-산도 측정 검사에 비해 역류에 대한 민감도와 특 이도가 낮음을 시사한다[51]. 경험적 치료 접근법은 역류 증상 지수(RSI>13) 및 역류 소견 점수(reflux finding score, RFS; $\mathrm{RFS}>7$ )와 같은 임상 점수의 활용과 3 개월간의 양성자 펌프 억제제 처방을 기반으로 하고 있다. 경험적 치료 시작 후 3-6개 월 후에 반응이 있을 때 인후두 역류질환 진단을 고려할 수 있다. 무반응 환자의 진단은 불확실하며 추가적인 24시간 다 채널 내강 임피던스-산도 측정 검사가 필요할 수 있다. 현재 치료에 대한 반응은 치료 시작 후 증상의 $50 \%$ 정도가 개선되 거나 역류 증상 지수가 5-10점 정도 감소하거나 치료 3-6개월 후 역류 증상 지수가 13 미만이고 역류 소견 점수가 7 미만인 경우를 말한다[11,12,52-54]. 전반적으로 인후두 역류질환 증 상의 대부분은 알레르기, 알코올, 담배, 약물, 천식 흡입치료 기, 환경 자극물질, 열악한 음성 위생, 근육 긴장과 같은 인후 두 점막에 영향을 미치는 여러 요인들과 더불어 혹은 역류 단 독으로도 발생할 수 있으므로 임상적 진단은 고려할 사항이 많고 어렵다. 따라서 경험적 치료 시험의 인후두 역류질환 진 단을 위해서는 인후두 역류질환 증상을 야기하는 모든 보 조 인자 또는 감별 진단을 검증하고 배제해야 한다[1]. 이러한 임상적인 특성에 대한 지식은 양성자 펌프 억제제 치료에 내 성을 가지고 있는 환자를 볼 때 더 중요하다. 이러한 접근법 은 위산이 점막 손상의 원인이라고 가정함과 동시에 펩신이나 담즙산(bile acid) 역시 염증 반응의 요인이 될 수 있다는 사실 에 기초한다. 또한 위장에서 내용물이 소장으로 빠져나갈 때 일부 환자에서 인두 반사 반응 (gag reflex)으로 이어지고 이것 은 인후두 역류질환 증상처럼 느껴지기도 한다. 하지만 이것은 PPI 치료로 잘 해결되지 않으며 신경근육 반사를 차단하는 약제를 사용하는 것이 도움이 된다고 알려져 있다.

\section{바이오마커로서의 펩신}

펩신은 위에서만 생성되므로 만약 이것이 인후두에서 검출 된다면 역류에 대한 특징적인 표지자가 될 수 있다. 비록 펩신 은 위의 산성 환경인 $\mathrm{pH}$ 2에서 활성화되지만 $\mathrm{pH}$ 8까지 안정 적으로 유지되므로 산도에 관계없이 위 역류액에서 효소를 확 인할 수 있다[55]. 하지만 기존 연구에서 타액의 펩신 수치는 인후두 역류질환 환자의 증상이나 삶의 질과 유의한 상관 관 계를 보이지 않았다[56]. 증상의 중증도를 나눠보았을 때도 타액 펩신 수치와 증상의 중증도와의 연관성은 발견된 적이 없다[29]. Wang 등[57]의 최근 메타분석에서는 인후두 역류 질환 진단에 있어서 타액의 펩신은 민감도와 특이도 측면에 서 24시간 다채널 내강 임피던스-산도 측정 검사에 비해 각 각 64\%와 68\%로 측정되었다. Johnston 등[3]은 역류 억제 수 술을 받은 인후두 역류질환 환자 10 명에서 펩신을 전향적으 로 분석하여 다음 항목들을 확인하였다. 1) 인후두 역류질환 환자의 타액에서 펩신이 검출될 확률; 2) 펩신 생검과 객담 검 출 사이의 일치율; 3) 역류 방지 수술의 상기도 펩신 예방 능력; 4) 역류 수술 후 치료 반응 예측에 펩신의 유용성 여부[58]. 해 당 연구에서 수술 후 9 명 중 6 명은 증상이 호전되었고, 2 명은 경미한 호전이 있었고, 1 명은 호전이 없었다. 펩신은 수술 전 9 명의 환자 중 8 명에서 발견되었다. 수술 전 5 명의 환자가 생 검과 객담 검사를 모두 받았으며 이들 중 4명은 생검에서 펩 신 검출과 객담 검사 사이에 상관 관계가 있었다. 수술 전 펩신 음성인 환자는 수술 후에도 음성으로 남아 있었고 $\mathrm{pH}$ 모니터 링 검사에서 역류의 정상화가 관찰되지 않은 유일한 환자였 다. 인후두 역류질환 환자에서 후두경 검사 및 $\mathrm{pH}$ 모니터링 은 임상 예측 능력이 부족한 반면, 펩신은 다음과 같은 이유 로 진단 테스트로서 유망하다. 1) 객관적인 위식도 역류질환 및 인후두 역류질환 징후가 있는 환자의 경우 기도에서 펩신 이 자주 검출되며(생검 또는 객담 검사) 질병의 주요 기전인 위 내용물의 역류와 기도 흡인에 대한 추가적인 증거를 제공한다; 2) 생검과 객담 검체 사이에 펩신 검출의 일치성이 좋으며, 이 는 검사의 임상 적용 가능성을 높여준다; 3) 역류 방지 수술은 상기도에서 펩신을 없애는 데 성공적이었다; 4) 역류 소견 점 수 및 DeMeester 점수와 달리 펩신 검출은 역류 방지 수술 후 인후두 역류질환의 임상적 개선을 잘 예측하는 것으로 보 인다. 효소 분석, 면역 조직 화학, 웨스턴 블롯(Western blot) 및 효소결합면역흡착검사(enzyme-linked immunosorbent assay)를 포함하여 위 역류물에서 펩신을 검출하는 데 사용 할 수 있는 다양한 기술들이 있으나 이것들의 공통점은 모 두 시간이 많이 걸리고 기술 지식이 필요하다는 한계가 있다. 이러한 펩신 검출 방법 및 진단 기준의 다양성은 인후두 역 류질환 환자의 타액 내 펩신 검사의 진단적 기준을 설정하기 
어렵게 하는 요인이다. 펩신을 이용한 진단키트로 Peptest (RDBiomed, Hull, UK)는 $16 \mathrm{ng} / \mathrm{mL}$ 의 펩신 검출 한계가 있 으나 상업적으로 이용 가능한 측면 유동 분석 장치(lateral flow device)이다[59]. 근위부 역류의 진단에 임상적인 필요성을 뒷받침할 수 있는 추가 데이터가 없어 현재까지 Peptest의 사 용은 어렵다. 그래서 펩신 검사 및 인후두 역류질환 진단 방 법을 표준화하는 것이 중요하다. 펩신은 타액에서 일시적으로 만 존재하며 따라서 타액의 수집 시기가 펩신 검출에 절대적 인 영향을 준다. 타액 수집 시기에 대한 연구에서 잠에서 깼을 때 높다는 결과도 있고 식후에 가장 높다는 결과도 있어 언제 가 적절한 시기인지에 대해서는 아직까지 논란이 있다[60-62]. 다수의 연구에서 펩신 검출은 민감도가 낮고 적절한 타액 수 집 시기에 대해 논란이 있음을 감안할 때, 반복 검사 또는 풀 링 샘플링을 하는 것이 특이도에 영향을 주지 않으면서도 단 일 샘플링보다 더 민감도를 높일 수 있는 방법이다[63]. 펩신 은 점막 세포에서 쉽게 세포내이입(endocytosis)이 될 수 있기 때문에 상부 소화호흡기 조직에서 펩신의 잘못된 검출로 이 어질 수 있음도 고려해야 한다[28]. 경험적으로 침에서 펩신의 검출 자체가 검사 양성을 시사하지만 문헌에서 제시하는 컷 오프 수준은 연구마다 다양하며 다만 위식도 역류질환 진단 을 위한 Peptest 연구에서는 최적의 민감도와 특이도를 갖는 컷오프(cutoff)를 $50 \mathrm{ng} / \mathrm{mL}$ 로 보고하였다[59,60]. 향후 연구 에서는 펩신 검사를 위한 최적의 샘플링 타이밍, 위치, 특성 및 임계 값 같은 많은 물음에 응답해야 한다는 숙제가 있다.

\section{치 료}

인후두 역류질환의 PPI 효능은 오랫동안 의문의 여지가 있 었지만 최근의 메타분석과 리뷰에 따르면 PPI는 인후두 역 류질환 증상 개선 효과적이었다[1]. 반면 진단 기준, 배제 기 준, 치료 및 치료효과 판정에 있어서 논문 간의 이질성은 그 결론에 대해서도 논쟁의 여지를 남기는 결과를 낳았다[1]. 역 류와 관련하여 많은 연관된 징후와 증상을 충분히 고려하지 않았던 것이 일부 연구에서 치료 효과 확인에 실패한 중요한 원인이 되었을 수 있다. PPI 치료에서 나이에 따른 치료 반응 이 다를 수 있다는 것도 중요한 고려사항이다. 60세 이상의 환 자들에서 그 이하의 환자들보다 PPI의 치료 반응이 유의하게 낮다는 보고가 있었다[64]. $\mathrm{H}_{2}$-수용체 길항제 $\left(\mathrm{H}_{2}\right.$-receptor antagonists)는 인후두 역류질환이나 위식도 역류질환의 2차 치료제로 사용하거나 PPI에 부분반응을 보인 환자에게 권장 되지만 작용시간이 4-8시간 정도로 비교적 짧다는 점은 치료 에 있어서 고려되어야 할 사항이다[65].

생활습관 교정과 식이요법이 첫 번째 치료 단계임에도 불구 하고 그 중요성은 소화기내과 및 이비인후과 전문의에 의해
오랫동안 과소평가되어 왔다. 실제로 일부 연구에서는 가벼 운 인후두 역류질환에 식이요법 단독으로 충분할 수 있다고 주장하고 있다[66]. 중등도 이상의 인후두 역류질환의 경우 식이요법을 잘 따르면 PPI 치료와 함께 징후 및 증상을 크게 개선할 수 있다는 보고가 있다[66-69]. 엄격한 알칼리성 식단 을 유지하는 것은 내성을 가진 인후두 역류질환 환자의 치료 에 결정적인 도움이 될 수 있다[67].

치료에 내성을 가진 환자는 치료 순응도를 평가해야 한다. 실제로 Pisegna 등[70]의 연구에서 PPI 치료를 처방받은 환자 의 $62.7 \%$ 가 치료에 순응하지 않았으며 이것이 치료 실패의 일 차 원인일 수 있다고 보고했다. 장기간의 치료에도 내성을 보 이는 경우 다른 인후두 감별 진단을 주의 깊게 검토해야 한다. 이전 약물 치료에서 저항성을 보인 환자의 경우 하부 식도 괄 약근 이완 억제제(baclofen)의 사용이 도움이 될 수 있다[71]. 위식도 역류질환에서보다 인후두 역류질환 환자에서 상대적 으로 약물치료 효과가 불분명하다[72]. 3-6개월간의 치료를 마 친 인후두 역류질환 환자에서조차 $66 \%$ 는 치료에 성공적이었 으나 25\%-50\% 환자에서는 만성적인 질병 경과를 보였다[7,73]. 이러한 환자에서는 식이조절이 중요하며 인후두 역류질환 재 발은 환자의 상태에 따라 단기 PPI 치료로도 조절될 수 있다. $\mathrm{PPI}$ 의 장기적인 부작용(예: 칼슘, 철분, 비타민 흡수 장애, 신 부전, 약물 상호 작용, 위축성 위염, 소아 성장 위험)이 있으므 로 처방 시에 이러한 부분은 반드시 고려되어야 한다[74].

\section{결 론}

인후두 역류질환은 앞서 역학, 병태생리, 진단 및 치료 문제 를 고려했을 때 복잡한 질병 스펙트럼을 갖는 질환이다. 현재 인후두 역류질환과 관련한 주요 문제는 여전히 신뢰할 수 있 는 명확한 진단 기법이 없다는 것이다. 펩신과 같은 위 역류 액 의 비산성 성분이 기도 질환의 병리학적 원인이며 임상 진단이 나 약물 개발의 잠재적인 표적임을 보여주는 실질적인 증거들 이 속속 등장하고 있다. 우선적으로 진단을 표준화하고 간편 화하기 위한 많은 연구가 필요할 것이다.

중심 단어: 인후두 역류; 진단; 치료.

Acknowledgments

This work was supported by the National Research Foundation of Korea (NRF) grant funded by the Korea government (MSIT) (No. 2020R1A5A2019413) and by a grant of the Korea Health Technology R\&D Project through the Korea Health Industry Development Institute (KHIDI), funded by the Ministry of Health \& Welfare, Republic of Korea (grant number : HI20C1205).

Conflicts of Interest

The authors have no financial conflicts of interest. 


\section{Authors' Contribution}

Conceptualization: all authors. Data curation: all authors. Formal analysis: all authors. Funding acquisition: all authors. Investigation: all authors. Methodology: all authors. Project administration: all authors. Resources: all authors. Software: all authors. Supervision: all authors. Validation: all authors. Visualization: all authors. Writing-original draft: all authors. Writing_review \& editing: all authors. Approval of final manuscript: all authors.

\section{REFERENCES}

1. Lechien JR, Saussez S, Schindler A, Karkos PD, Hamdan AL, Harmegnies B, et al. Clinical outcomes of laryngopharyngeal reflux treatment: A systematic review and meta-analysis. Laryngoscope 2019;129(5):117487.

2. Koufman JA, Aviv JE, Casiano RR, Shaw GY. Laryngopharyngeal reflux: Position statement of the committee on speech, voice, and swallowing disorders of the American Academy of Otolaryngology-Head and Neck Surgery. Otolaryngol Head Neck Surg 2002;127(1):32-5.

3. Johnston N, Ondrey F, Rosen R, Hurley BP, Gould J, Allen J, et al. Airway reflux. Ann N Y Acad Sci 2016;1381(1):5-13.

4. Sereg-Bahar M, Jerin A, Jansa R, Stabuc B, Hocevar-Boltezar I. Pepsin and bile acids in saliva in patients with laryngopharyngeal reflux - a prospective comparative study. Clin Otolaryngol 2015;40(3):234-9.

5. Amarasiri DL, Pathmeswaran A, de Silva HJ, Ranasinha CD. Response of the airways and autonomic nervous system to acid perfusion of the esophagus in patients with asthma: A laboratory study. BMC Pulm Med 2013;13:33.

6. Lechien JR, Saussez S, Karkos PD. Laryngopharyngeal reflux disease: Clinical presentation, diagnosis and therapeutic challenges in 2018. Curr Opin Otolaryngol Head Neck Surg 2018;26(6):392-402.

7. Koufman JA. The otolaryngologic manifestations of gastroesophageal reflux disease (GERD): A clinical investigation of 225 patients using ambulatory 24-hour $\mathrm{pH}$ monitoring and an experimental investigation of the role of acid and pepsin in the development of laryngeal injury. Laryngoscope 1991;101(S53):1-78.

8. Chen XM, Li Y, Guo WL, Wang WT, Lu M. Prevalence of laryngopharyngeal reflux disease in Fuzhou region of China. Zhonghua Er Bi Yan Hou Tou Jing Wai Ke Za Zhi 2016;51(12):909-13.

9. Spantideas N, Drosou E, Bougea A, Assimakopoulos D. Laryngopharyngeal reflux disease in the Greek general population, prevalence and risk factors. BMC Ear Nose Throat Disord 2015;15:7.

10. Koufman JA, Amin MR, Panetti M. Prevalence of reflux in 113 consecutive patients with laryngeal and voice disorders. Otolaryngol Head Neck Surg 2000;123(4):385-8.

11. Lechien JR, Finck C, Khalife M, Huet K, Delvaux V, Picalugga M, et al. Change of signs, symptoms and voice quality evaluations throughout a 3- to 6-month empirical treatment for laryngopharyngeal reflux disease. Clin Otolaryngol 2018;43(5):1273-82.

12. Lee YS, Choi SH, Son YI, Park YH, Kim SY, Nam SY. Prospective, observational study using rabeprazole in 455 patients with laryngopharyngeal reflux disease. Eur Arch Otorhinolaryngol 2011;268(6):863-9.

13. Habermann W, Schmid C, Neumann K, Devaney T, Hammer HF. Reflux symptom index and reflux finding score in otolaryngologic practice. J Voice 2012;26(3):e123-7.

14. Jaspersen D, Kulig M, Labenz J, Leodolter A, Lind T, Meyer-Sabellek $\mathrm{W}$, et al. Prevalence of extra-oesophageal manifestations in gastrooesophageal reflux disease: An analysis based on the ProGERD Study. Aliment Pharmacol Ther 2003;17(12):1515-20.

15. Dore MP, Pedroni A, Pes GM, Maragkoudakis E, Tadeu V, Pirina P, et al. Effect of antisecretory therapy on atypical symptoms in gastroesophageal reflux disease. Dig Dis Sci 2007;52(2):463-8.

16. Fuchs HF, Müller DT, Berlth F, Maus MK, Fuchs C, Dübbers M, et al.
Simultaneous laryngopharyngeal pH monitoring (Restech) and conventional esophageal $\mathrm{pH}$ monitoring-correlation using a large patient cohort of more than 100 patients with suspected gastroesophageal reflux disease. Dis Esophagus 2018;31(10):1-8.

17. Drinnan M, Powell J, Nikkar-Esfahani A, Heading RC, Doyle J, Griffin SM, et al. Gastroesophageal and extraesophageal reflux symptoms: similarities and differences. Laryngoscope 2015;125(2):424-30.

18. Nason KS, Murphy T, Schindler J, Schipper PH, Hoppo T, Diggs BS, et al. A cross-sectional analysis of the prevalence of Barrett esophagus in otolaryngology patients with laryngeal symptoms. J Clin Gastroenterol 2013;47(9):762-8.

19. Mosli M, Alkhathlan B, Abumohssin A, Merdad M, Alherabi A, Marglani O, et al. Prevalence and clinical predictors of LPR among patients diagnosed with GERD according to the reflux symptom index questionnaire. Saudi J Gastroenterol 2018;24(4):236-41.

20. Chen M, Hou C, Chen T, Lin Z, Wang X, Zeng Y. Reflux symptom index and reflux finding score in 91 asymptomatic volunteers. Acta Otolaryngol 2018;138(7):659-63.

21. Gao CK, Li YF, Wang L, Han XY, Wu T, Zeng FF, et al. Different cutoffs of the reflux finding score for diagnosing laryngopharyngeal reflux disease should be used for different genders. Acta Otolaryngol 2018;138(9):848-54.

22. Mendelsohn AH. The effects of reflux on the elderly: The problems with medications and interventions. Otolaryngol Clin North Am 2018;51(4):779-87.

23. Lechien JR, Finck C, Huet K, Khalife M, Fourneau AF, Delvaux V, et al. Impact of age on laryngopharyngeal reflux disease presentation: A multi-center prospective study. Eur Arch Otorhinolaryngol 2017; 274(10):3687-96.

24. Hicks DM, Ours TM, Abelson TI, Vaezi MF, Richter JE. The prevalence of hypopharynx findings associated with gastroesophageal reflux in normal volunteers. J Voice 2002;16(4):564-79.

25. Chang BA, MacNeil SD, Morrison MD, Lee PK. The reliability of the reflux finding score among general otolaryngologists. J Voice 2015; 29(5):572-7.

26. Musser J, Kelchner L, Neils-Strunjas J, Montrose M. A comparison of rating scales used in the diagnosis of extraesophageal reflux. J Voice 2011;25(3):293-300.

27. Lechien JR, Schindler A, De Marrez LG, Hamdan AL, Karkos PD, Harmegnies B, et al. Instruments evaluating the clinical findings of laryngopharyngeal reflux: A systematic review. Laryngoscope 2019; 129(3):720-36.

28. Lechien JR, Saussez S, Harmegnies B, Finck C, Burns JA. Laryngopharyngeal reflux and voice disorders: A multifactorial model of etiology and pathophysiology. J Voice 2017;31(6):733-52.

29. Wood JM, Hussey DJ, Woods CM, Astill D, I Watson D, Lee B, et al. Does gene expression in laryngeal subsites differ between patients with laryngopharyngeal reflux and controls? Clin Otolaryngol 2018; 43(1):158-63.

30. Ali Mel-S, Bulmer DM, Dettmar PW, Pearson JP. Mucin gene expression in reflux laryngeal mucosa: Histological and in situ hybridization observations. Int J Otolaryngol 2014;2014:264075.

31. Hanson DG, Jiang J, Chi W. Quantitative color analysis of laryngeal erythema in chronic posterior laryngitis. J Voice 1998;12(1):78-83.

32. Arruda Henry MA, Martins RH, Lerco MM, Carvalho LR, Lamônica-Garcia VC. Gastroesophageal reflux disease and vocal disturbances. Arq Gastroenterol 2011;48(2):98-103.

33. Jin BJ, Lee YS, Jeong SW, Jeong JH, Lee SH, Tae K. Change of acoustic parameters before and after treatment in laryngopharyngeal reflux patients. Laryngoscope 2008;118(5):938-41.

34. Ramírez DAM, Jiménez VMV, López XH, Ysunza PA. Acoustic analysis of voice and electroglottography in patients with laryngopharyn- 
geal reflux. J Voice 2018;32(3):281-4.

35. Doo JG, Kim SI, Park JM, Kwon OE, Lee YC, Eun YG. Changes in pharyngeal baseline impedance in patients with laryngopharyngeal reflux. Otolaryngol Head Neck Surg 2020;163(3):563-8.

36. Belafsky PC, Postma GN, Koufman JA. Validity and reliability of the reflux symptom index (RSI). J Voice 2002;16(2):274-7.

37. Carrau RL, Khidr A, Gold KF, Crawley JA, Hillson EM, Koufman JA, et al. Validation of a quality-of-life instrument for laryngopharyngeal reflux. Arch Otolaryngol Head Neck Surg 2005;131(4):315-20.

38. Lechien JR, Schindler A, Hamdan AL, Bobin F, Barillari MR, Harmegnies $\mathrm{B}$, et al. The development of new clinical instruments in laryngopharyngeal reflux disease: The international project of young otolaryngologists of the International Federation of Oto-rhino-laryngological Societies. Eur Ann Otorhinolaryngol Head Neck Dis 2018;135(5S):S8591.

39. Lechien JR, Bobin F, Muls V, Thill MP, Horoi M, Ostermann K, et al. Validity and reliability of the reflux symptom score. Laryngoscope 2020;130(3):E98-107.

40. Galli J, Cammarota G, De Corso E, Agostino S, Cianci R, Almadori G, et al. Biliary laryngopharyngeal reflux: A new pathological entity. Curr Opin Otolaryngol Head Neck Surg 2006;14(3):128-32.

41. Lee JS, Jung AR, Park JM, Park MJ, Lee YC, Eun YG. Comparison of characteristics according to reflux type in patients with laryngopharyngeal reflux. Clin Exp Otorhinolaryngol 2018;11(2):141-5.

42. Kim SI, Kwon OE, Na SY, Lee YC, Park JM, Eun YG. Association between 24-hour combined multichannel intraluminal impedance-pH monitoring and symptoms or quality of life in patients with laryngopharyngeal reflux. Clin Otolaryngol 2017;42(3):584-91.

43. Hoppo T, Sanz AF, Nason KS, Carroll TL, Rosen C, Normolle DP, et al. How much pharyngeal exposure is "normal"? Normative data for laryngopharyngeal reflux events using hypopharyngeal multichannel intraluminal impedance (HMII). J Gastrointest Surg 2012;16(1):1624; discussion 24-5

44. Maldonado A, Diederich L, Castell DO, Gideon RM, Katz PO. Laryngopharyngeal reflux identified using a new catheter design: Defining normal values and excluding artifacts. Laryngoscope 2003;113:34955.

45. Jacob P, Kahrilas PJ, Herzon G. Proximal esophageal pH-metry in patients with 'reflux laryngitis'. Gastroenterology 1991;100(2):305-10.

46. Eubanks TR, Omelanczuk PE, Maronian N, Hillel A, Pope CE 2nd, Pellegrini CA. Pharyngeal $\mathrm{pH}$ monitoring in 222 patients with suspected laryngeal reflux. J Gastrointest Surg 2001;5(2):183-90; discussion 190-1.

47. Gupta R, Sataloff RT. Laryngopharyngeal reflux: Current concepts and questions. Curr Opin Otolaryngol Head Neck Surg 2009;17(3): 143-8.

48. Chander B, Hanley-Williams N, Deng Y, Sheth A. 24 versus 48-hour bravo pH monitoring. J Clin Gastroenterol 2012;46(3):197-200.

49. Ford CN. Evaluation and management of laryngopharyngeal reflux. JAMA 2005;294(12):1534-40.

50. Gupta N, Green RW, Megwalu UC. Evaluation of a laryngopharyngeal reflux management protocol. Am J Otolaryngol 2016;37(3):24550.

51. Gyawali CP, Kahrilas PJ, Savarino E, Zerbib F, Mion F, Smout AJPM, et al. Modern diagnosis of GERD: The Lyon Consensus. Gut 2018;67(7): 1351-62.

52. Lien HC, Wang CC, Lee SW, Hsu JY, Yeh HZ, Ko CW, et al. Responder definition of a patient-reported outcome instrument for laryngopharyngeal reflux based on the US FDA guidance. Value Health 2015; 18(4):396-403.

53. Masaany M, Marina MB, Sharifa Ezat WP, Sani A. Empirical treatment with pantoprazole as a diagnostic tool for symptomatic adult la- ryngopharyngeal reflux. J Laryngol Otol 2011;125(5):502-8.

54. Lechien JR, Huet K, Khalife M, Fourneau AF, Delvaux V, Piccaluga $\mathrm{M}$, et al. Impact of laryngopharyngeal reflux on subjective and objective voice assessments: A prospective study. J Otolaryngol Head Neck Surg 2016;45(1):59.

55. Piper DW, Fenton BH. pH stability and activity curves of pepsin with special reference to their clinical importance. Gut 1965;6(5):506-8.

56. Jung AR, Kwon OE, Park JM, Dong SH, Jung SY, Lee YC, et al. Association between pepsin in the saliva and the subjective symptoms in patients with laryngopharyngeal reflux. J Voice 2019;33(2):150-4.

57. Wang J, Zhao Y, Ren J, Xu Y. Pepsin in saliva as a diagnostic biomarker in laryngopharyngeal reflux: A meta-analysis. Eur Arch Otorhinolaryngol 2018;275(3):671-8.

58. Wassenaar E, Johnston N, Merati A, Montenovo M, Petersen R, Tatum $\mathrm{R}$, et al. Pepsin detection in patients with laryngopharyngeal reflux before and after fundoplication. Surg Endosc 2011;25:3870-6.

59. Saritas Yuksel E, Hong SK, Strugala V, Slaughter JC, Goutte M, Garrett CG, et al. Rapid salivary pepsin test: Blinded assessment of test performance in gastroesophageal reflux disease. Laryngoscope 2012; 122(6):1312-6.

60. Klimara MJ, Johnston N, Samuels TL, Visotcky AM, Poetker DM, Loehrl TA, et al. Correlation of salivary and nasal lavage pepsin with MII-pH testing. Laryngoscope 2020;130(4):961-6.

61. Na SY, Kwon OE, Lee YC, Eun YG. Optimal timing of saliva collection to detect pepsin in patients with laryngopharyngeal reflux. Laryngoscope 2016;126(12):2770-3.

62. Weitzendorfer M, Antoniou SA, Schredl P, Witzel K, Weitzendorfer IC, Majerus A, et al. Pepsin and oropharyngeal $\mathrm{pH}$ monitoring to diagnose patients with laryngopharyngeal reflux. Laryngoscope 2020; 130(7):1780-6.

63. Fortunato JE, D’Agostino RB Jr, Lively MO. Pepsin in saliva as a biomarker for oropharyngeal reflux compared with 24-hour esophageal impedance/pH monitoring in pediatric patients. Neurogastroenterol Motil 2017;29(2):e12936.

64. Lee YC, Lee JS, Kim SW, Kwon KH, Eun YG. Influence of age on treatment with proton pump inhibitors in patients with laryngopharyngeal reflux disease: A prospective multicenter study. JAMA Otolaryngol Head Neck Surg 2013;139(12):1291-5.

65. Kroch DA, Madanick RD. Medical treatment of gastroesophageal reflux disease. World J Surg 2017;41(7):1678-84

66. Zalvan CH, Hu S, Greenberg B, Geliebter J. A comparison of alkaline water and Mediterranean diet vs proton pump inhibition for treatment of laryngopharyngeal reflux. JAMA Otolaryngol Head Neck Surg 2017;143(10):1023-9.

67. Koufman JA. Low-acid diet for recalcitrant laryngopharyngeal reflux: Therapeutic benefits and their implications. Ann Otol Rhinol Laryngol 2011;120(5):281-7.

68. Lechien JR, Huet K, Khalife M, De Marrez LG, Finck C, Harmegnies $\mathrm{B}$, et al. Alkaline, protein, low-fat and low-acid diet in laryngopharyngeal reflux disease: Our experience on 65 patients. Clin Otolaryngol 2019;44(3):379-84.

69. Yang J, Dehom S, Sanders S, Murry T, Krishna P, Crawley BK. Treating laryngopharyngeal reflux: Evaluation of an anti-reflux program with comparison to medications. Am J Otolaryngol 2018;39(1):50-5.

70. Pisegna JM, Yang S, Purcell A, Rubio A. A mixed-methods study of patient views on reflux symptoms and medication routines. J Voice 2017;31(3):381.e15-381.e25.

71. Lee YC, Jung AR, Kwon OE, Kang JW, Huh JH, Eun YG. The effect of baclofen combined with a proton pump inhibitor in patients with refractory laryngopharyngeal reflux: A prospective, open-label study in thirty-two patients. Clin Otolaryngol 2019;44(3):431-4.

72. Mazzini Gda S, Gurski RR. Impact of laparoscopic fundoplication 
for the treatment of laryngopharyngeal reflux: Review of the literature. Int J Otolaryngol 2012;2012:291472.

73. Lin RJ, Sridharan S, Smith LJ, Young VN, Rosen CA. Weaning of proton pump inhibitors in patients with suspected laryngopharyngeal reflux disease. Laryngoscope 2018;128(1):133-7.

74. Eusebi LH, Rabitti S, Artesiani ML, Gelli D, Montagnani M, Zagari RM, et al. Proton pump inhibitors: Risks of long-term use. J Gastroenterol Hepatol 2017;32(7):1295-302. 